\title{
EMISI FORMALDEHIDA DARI PAPAN LANTAI LAMINA KOMBINASI DENGAN BATANG KELAPA YANG MENGGUNAKAN TANIN RESORSINOL FORMALDEHIDA
}

\author{
Supriyono Eko Wardoyo ${ }^{1}$, Adi Santoso ${ }^{2}$ dan Sri Wuryani Sugiarti \\ ${ }^{1}$ FMIPA Universitas Nusa Bangsa, ${ }^{2}$ Puslitbang Hasil Hutan Bogor \\ ${ }^{1}$ J1. K. H. Sholeh Iskandar, Cimanggu, Tanah Sareal-Bogor 16166 \\ 1e-mail : supriyono.wardoyo@yahoo.com
}

\begin{abstract}
Formaldehyde Emissions from Floor Boards Lamina Combination with The Coconut Bar Using Tanin Resorcinol Formaldehyde
\end{abstract}

Trunks of coconut (Cocos nucifera L.) has been widely used as both structural and non structural materials, including home furnishings, furniture, toys, crates, and so on. In the utilization of coconut trunks required special handling to produce a high quality product. How to handle it needs through the process of densification or impregnation by using a copolymer of Tanin Resorcinol Formaldehyde (TRF) in the vacuum press. In the case to reduce the scarcity of the wood, modification between coconut wood with other wood species in laminated floor board products is needed. The research was done by the method of vacuum press in the Laboratory for Products Compound and Wood Preservation, Center Research and Development for Forest Products, Bogor. The tests were performed the physical properties consist of specific gravity and moisture content or the chemical properties of formaldehyde emissions by using Spectrophotometer. The results indicated that by using TRF copolymer (1: 0.5: 2) and viscosity 0.88 centripoise, formaldehyde emissions of the combination of the wood was very well and meet the requirements ( 0.30 to $0.40 \mathrm{mg} / \mathrm{L})$ and were included in the category of very safe.

Keywords : Emissions of formaldehyde, Laminated boards, Trunks of coconut, Tanin resorcinol formaldehyde

\begin{abstract}
ABSTRAK
Batang kelapa (Cocos nucifera L.) telah banyak digunakan baik sebagai bahan struktural maupun non structural, seperti perkakas rumah tangga, mebel, mainan, peti dan lain sebagainya. Dalam pemanfaatannya batang kelapa tersebut diperlakukan penanganan khusus untuk menghasilkan suatu produk yang berkualitas tinggi. Adapun cara penanganannya adalah dapat melalui proses densifikasi ataupun impregnaasi dengan menggunakan suatu kopolimer Tanin Resorsinol Formaldehida menggunakan metode vakum tekan. Dalam hal ini untuk mengurangi kelangkaan dari kayu tersebut maka dilakukan modifikasi antara kayu kelapa dengan jenis kayu lainnya pada produk papan lantai lamina. Untuk itu dilakukan penelitian pengujian dengan metode vakum tekan di Laboratorium Produk Majemuk dan Pengawetan Kayu, Pusat Penelitian dan Pengembangan Hasil Hutan, Bogor . Adapun pengujian yang dilakukan adalah sifat fisika terdiri atas bobot jenis, kadar air, dan sifat kimia emisi formaldehida yang diuji dengan menggunakan Spectrophotometer. Hasil penelitian ini menunjukan bahwa dengan menggunakan kopolimer TRF (1:0,5:2) dengan kekentalan 0,88 centripoise, emisi formaldehida yang dihasilkan dari kombinasi kayu tersebut sangat baik dan memenuhi persyaratan $(0,30-0,40 \mathrm{mg} / \mathrm{L}) \mathrm{dan}$ termasuk dalam kategori sangat aman.
\end{abstract}

Kata kunci : Emisi formaldehida, Papan lamina, Batang kelapa, Tanin resorsinol formaldehida

\section{PENDAHULUAN}

Potensi kayu yang berasal dari hutan tanaman industri (HTI) dan hutan rakyat diperkirakan mencapai lebih dari
$2.000 .000 \mathrm{~m}^{3}$ per tahun sehingga berpotensi menjadi komoditi ekspor pada masa yang akan datang. Beberapa kayu dari hutan tanaman mempunyai sifat yang 
lebih baik dibandingkan kayu' dari hutan alam.

Menurut Rachman (1990), dolok dari hutan tanaman industri umumnya kecil, tetapi bentuknya relatif lebih baik dari tanaman umumnya. Sedangkan rendemen kayu gergajian dapat mencapai lebih dari 55\% dengan konsumsi tenaga yang diperlukan cukup rendah. Dalam penggunaannya, kayu HTI akan lebih baik dari kayu meranti karena mempunyai sifat mudah dalam hal pengetaman dan pembentukan (moulding). Di lain pihak, Memed (1990) menjelaskan bahwa sifat dari perekatan beberapa jenis kayu dari hutan tanaman dapat dipergunakan untuk mengatasi keterbatasan ukuran kayu utuh (solid) dan mahal dengan menggunakan teknologi perekatan. Sementara sifat keawetannya yang rendah dapat ditingkatkan dengan cara diawetkan (Martawijaya,1990). Informasi tersebut menunjukan bahwa kayu dari hutan tanaman secara teknis memiliki potensi untuk digunakan sebagai kayu pertukangan.

Kayu kelapa (Cocos nucifera L.) dapat dimanfaatkan sebagai bahan baku untuk konstruksi bangunan terutama bagian kerasnya. Hal ini sudah lazim digunakan di pedesaan karena bagian kayu kelapa tersebut dianggap kuat dan awet. Pohon kelapa berakar serabut, tidak beraturan, bentuk batang lancip, tinggi dapat mencapai 5 - $30 \mathrm{~m}$, dengan diameter batang rata - rata $25 \mathrm{~cm}$ (Barly, 2001).

Selain kayu dari hutan tanaman, kayu yang berasal dari perkebunan seperti kayu kelapa mempunyai peluang pula sebagai kayu pengganti, karena dalam beberapa hal sifat batang kelapa dapat melebihi sifat kayu. Kekuatan batang kelapa mulai dari bagian pangkal, tengah, ujung serta bagian luar dan dalam dapat berbeda. Hal tersebut disebabkan oleh perbedaan kerapatan pada setiap bagiannya, sehingga akibatnya belum semua bagian dapat dimanfaatkan sebagai bahan konstruksi bangunan. Sedangkan sifat lain yang tidak menguntungkan adalah sangat peka terhadap serangan organisme perusak kayu, terutama bila digunakan pada tempat yang berhubungan langsung dengan tanah atau dipasang di tempat terbuka.

Pengolahan kayu dengan memanfaatkan teknologi perekatan untuk masa sekarang cenderung meningkat, sejalan dengan meningkatnya keterbatasan ukuran kayu, sehingga industri kayu banyak memodifikasi atau mendiversifikasi kayu berukuran kecil menjadi ukuran besar, salah satunya adalah kayu lamina yang diperuntukan antara lain untuk lantai (laminated parquet flooring, LPF) (Blanchet, et al. 2003). Kayu lamina atau balok majemuk adalah suatu balok yang diperoleh dari perekatan kayu, dapat berbentuk lurus, melengkung atau gabungan dari keduanya dengan arah sejajar antara satu sama lainnya (Anonim, 1974). Dalam penggunaannya, baik sebagai konstruksi atau papan lantai lamina, kayu lamina mempunyai beberapa kelebihan antara lain dapat dibuat untuk membentuk suatu penampang yang sangat kuat atau lebih kuat dari balok tunggal biasa. Pelapisan dapat disusun sedemikian rupa sehingga bagian-bagian yang mendapat tegangan terbesar akan memuat kualitas yang lebih tinggi, selain itu suatu rangka kayu berlapis majemuk umumnya lebih tahan dari kebakaran daripada suatu rangka kayu batang (Yap, 1984).

Produk - produk perekatan yang menggunakan perekat berbahan dasar formaldehida disinyalir akan mengemisikan formaldehidanya sehingga dikhawatirkan akan mengganggu kesehatan bila digunakan di dalam ruangan yang relatif tertutup. Namun sampai saat ini belum diketahui sejauh mana tingkat formaldehida yang diemisikan oleh produk perekatan berupa lantai kayu lamina yang menggunakan tanin resorsinol formaldehida. Menurut Petterson (1976), bahwa pencemaran ini dapat berpengaruh sinergik terhadap manusia, yaitu pada selaput lendir, hidung, mata, tenggorokan dan gangguan pernafasan serta menurunkan daya penciuman. Menurut Christensen et al. (1981), kandungan formaldehida bebas dalam perekat akan berpengaruh terhadap emisi formaldehida. Karena semakin besar formaldehida bebas 
dalam perekat, maka akan semakin besar pula emisi formaldehida yang dikeluarkan.

Selain jenis perekat, kadar perekat (jumlah perekat) laju pematangan, waktu kempa dan kelembaban juga dapat menyebabkan terlepasnya formaldehida (Pizzi, 1994). Emisi formaldehida adalah peristiwa pengeluaran atau pemancaran gas formaldehida dan berasal dari perekat yang digunakan dalam pembuatan suatu produk, dimana perekat tersebut mengandung formaldehida. Terikatnya formaldehida tersebut akan dibebaskan kembali saat terjadi hidrolisis (SNI, 1998). Menurut Rofflael (1993), besarnya emisi formaldehida tergantung pada faktor internal, seperti kayu, komposisi perekat yang digunakan, zat aditif, pengempaan, kondisi saat pembuatan, serta faktor eksternal, seperti kelembaban, temperatur, $\mathrm{pH}$, pertukaran udara dalam ruangan.

Penelitian ini bertujuan untuk mengetahui emisi formaldehida dari papan lantai lamina dengan kombinasi jenis kayu dan batang kelapa dengan menggunakan perekat tanin resorsinol formaldehida (TRF). Berdasarkan srtukturnya tanin resorsinol formaldehida (TRF) merupakan senyawa polifenol, adalah perekat yang mirip dengan resin fenol resorsinol formaldehida (PRF). (Pizzi, 1994). Mengingat bahwa hingga saat ini belum banyak data mengenai emisi formaldehida dari produk perekatan dengan kombinasi jenis kayu khususnya yang menggunakan kayu dari hutan tanaman dan perkebunan berperekat tanin, maka dilakukan penelitian mengenai emisi formaldehida dari papan lantai lamina yang dibuat dari kombinasi kayu asal hutan tanaman dan perkebunan dengan perekat tanin. Struktur kimia Tanin Resorsinol Formaldehida dapat dilihat pada Gambar 1a.

Tanin ditambah dengan sedikit fenol atau urea, resorsinol dan formaldehida akan memberikan kekuatan rekat yang baik, tahan terhadap air dan dapat digunakan untuk perekat kayu lapis, kayu lamina, papan partikel, dan produk lainnya (Tsoumist, 1991).

Salah satu sifat produk perekatan yang dibuat dengan perekat yang mengandung formaldehida adalah terjadinya emisi formaldehida, sehingga dikhawatirkan akan mencemari lingkungan yang berupa gangguan terhadap kesehatan bila digunakan pada ruangan yang relatif tertutup.

\section{BAHAN DAN METODE PENELITIAN}

\section{A. Bahan}

Bahan yang digunakan adalah resin tanin resorsinol formaldehida (TRF), formaldehida $37 \%$, bagian lunak batang kelapa yang berumur 19 tahun (berasal dari Balai Penelitian Kayu Kelapa, Parung Kuda, Sukabumi, Jawa Barat). Bahan kayu lain adalah Jati (Tectona garndis), dan tiga jenis kayu HTI, yaitu Mangium (Acasia mangium), Tusam (Pinus merkusii) dan Gmelina (Gmelina arborea) berasal dari Sukabumi, Jawa Barat.

\section{B. Alat - alat}

Peralatan yang digunakan adalah oven, timbangan, alat pelabur perekat, jangka sorong, desikator, spektrofotometer dan peralatan gelas kimia.

\section{Metode Penelitian}

\section{Persiapan bahan baku}

Dari bagian batang pohon kelapa, diambil pelepah paling bawah dan dijadikan balok dengan ukuran lebih kurang 6,6 m. Kemudian digergaji untuk mengambil bagian tengah serta menjadikan balok dengan ukuran $10 \mathrm{~cm}$ x $11 \mathrm{~cm}$ x 200 $\mathrm{cm}$, Lalu diracik untuk pembuatan papan dengan ukuran $1,5 \mathrm{~cm} \times 10 \mathrm{~cm} \times 50 \mathrm{~cm}$, kemudian diserut halus sebagai contoh uji. Perlakuan serupa dilakukan juga terhadap kayu jati, mangium, tusam dan gmelina.

Sebelum direkat, contoh terlebih dahulu dikeringkan dalam dapur pengering pada suhu $103 \pm 2^{0} \mathrm{C}$ selama satu minggu hingga kadar air mencapai $10-12 \%$. Kemudian perekat TRF dilaburkan pada permukaan arah lebar papan dengan bobot labur $85 \mathrm{~g} / \mathrm{m}^{2}$ permukaan, selanjutnya papan direkatkan satu sama lain dengan tekanan 1,0 MPa selama 8 jam pada suhu 
kamar. Perlakuan juga dilakukan terhadap empat kombinasi jenis kayu (jati, mangium, tusam dan gmelina) dengan batang kelapa menjadi lima perlakuan :
1. Kelapa - Kelapa (k1)
2. Kelapa - Jati (k2)
3. Kelapa-Mangium (k3)
4. Kelapa-Tusam (k4)
5. Kelapa-Gmelina (k5)

Cara kerja tersebut diatas dapat dibuatkan diagram alir penelitian seperti pada Gambar 2.

\section{Rancangan Penelitian}

Penelitian ini menggunakan rancangan acak lengkap (RAL) dengan ulangan tiga kali untuk masing - masing bagian dari kombinasi jenis kayu dengan batang kelapa.

Model matematika :

$$
Y i j=\mu+T i+C i j
$$

Keterangan :
Yij = Nilai pengamatan yang memperoleh perlakuan ke - i pada ulangan ke $\mathrm{j}$

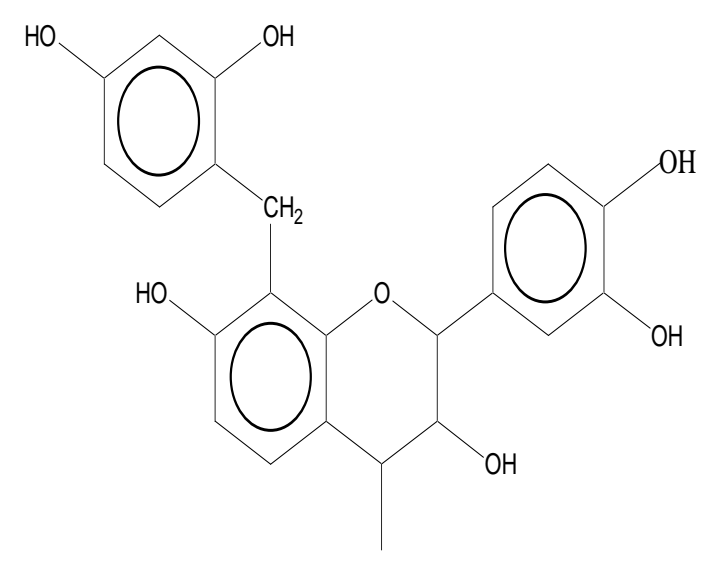

Tanin Resorsinol Formaldehida

Gambar 1a. Tanin Resorsinol Formaldehida

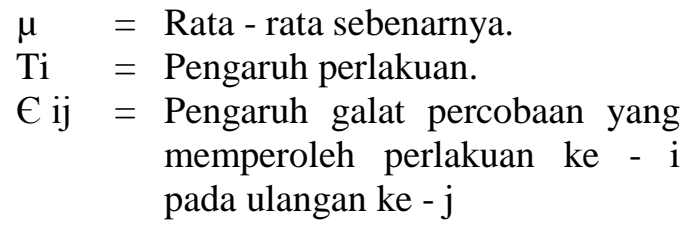

\section{Parameter yang di uji :}

\section{a. Bobot Jenis}

Bobot jenis adalah perbandingan bobot dan volume kayu dalam keadaan kering udara dengan kadar air sekitar 10 $12 \%$. Nilai bobot jenis yang dicantumkan adalah nilai rata - ratanya.

\section{b. Kadar Air}

Masing - masing contoh diuji dan dihitung dalam keadaan kering udara kemudian dimasukkan dalam oven ( $103 \pm$ $2^{0} \mathrm{C}$ ), timbang hingga bobot konstan. Nilai kadar air dihitung dengan rumus sebagai berikut :

Nilai Kadar Air $=\frac{(\text { BKU }- \text { BKT })}{\text { BKT }}$ X $100 \%$

Keterangan :

$\mathrm{BKU}=$ Bobot Kering Udara (gram)

BKT $=$ Bobot Kering Tanur (gram)

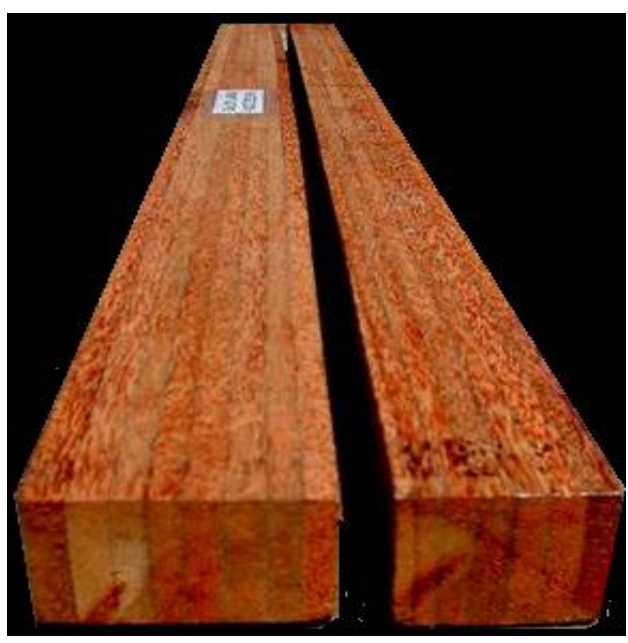

Gambar 1b. Contoh papan lantai lamin 


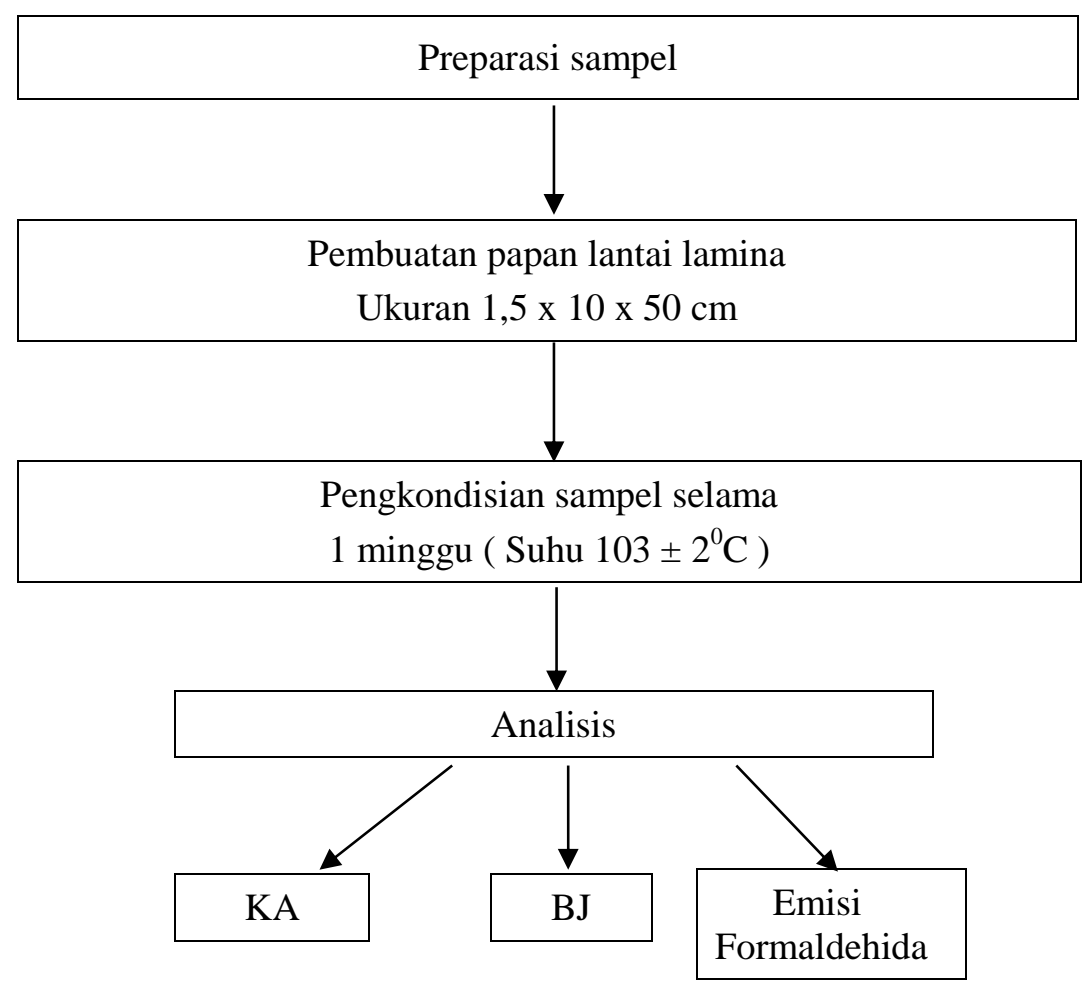

Keterangan :

* KA = Kadar Air

$* \mathrm{BJ}=$ Bobot Jenis

Gambar 2. Diagram alir penelitian

\section{c. Emisi Formaldehida}

Prinsip penentuan konsentrasi formaldehida teremisi adalah :

Mereaksikan gas formaldehida yang tertangkap oleh suatu cairan $(\mathrm{H} 2 \mathrm{O}$, $\mathrm{NaSO} 3$, air suling dan lain - lain) dengan menggunakan indikator - indikator tertentu yang akan membentuk suatu senyawa komplek berwarna tertentu. Analisa emisi formaldehida adalah pengukuran absorbansi yang terjadi dari larutan contoh serta mempunyai intensitas secara kuantitatif dilakukan menggunakan spektrosfotometer. Dimana senyawa ini akan menghasilkan warna hijau kekuningan yang mempunyai panjang gelombang maksimum $412 \mathrm{~nm}$. (Christian, 1986).
1. Persiapan larutan induk dan larutan pereaksi

- Larutan induk formaldehida (larutan standar) :

Larutan formaldehida $37 \%$ dipipet $1 \mathrm{ml}$, lalu masukkan ke dalam, labu ukur $1000 \mathrm{ml}$, lalu encerkan dengan aqudest hingga tanda batas.

Dari larutan induk formladehida dibuat suatu deret standar dengan konsentrasi $0,5,10,20,50$, dan $100 \mathrm{ml} \mathrm{ke}$ dalam masing - masing 6 buah labu ukur $100 \mathrm{ml}$, lalu tambahkan larutan asetilaseton amonium asetat sebanyak 25,0 ml, kemudian encerkan hingga tanda batas.

Larutan dipanaskan dalam penangas air pada suhu $60 \pm 5^{\circ} \mathrm{C}$ sel;ama 10 menit, angkat dan dinginkan hingga suhu kamar. Lakukan pengukuran dengan 
spektrofotometer pada panjang gelombang $412 \mathrm{~nm}$.

- Larutan asetilaseton amoniumasetat :

Timbang amonium asetat $150 \mathrm{gr}$, larutkan dengan $300 \mathrm{ml}$ aquadest dalam labu ukur $1000 \mathrm{ml}$, kemudian tambahkan 3 $\mathrm{ml}$ asam asetat glacial dan $2 \mathrm{ml}$ asetil aseton, lalu encerkan hingga tanda batas.

Penyimpanan larutan dilakukan dalam botol coklat untuk menghindari terjadinya perubahan warna dari larutan sehingga larutan tidak dapat dipergunakan bila telah berubah warnanya.

\section{Penetapan emisi formaldehida}

\section{- Pengkondisian contoh}

diikat dengan $\begin{gathered}\text { Masing } \\ \text { denang contoh uji }\end{gathered}$
kemudian digantung ( $\pm 1 \mathrm{~cm}$ di atas permukaan air) dalam botol $500 \mathrm{ml}$ yang berisi aqudes sebanyak $50 \mathrm{ml}$. Kemudian dimasukkan dalam oven pada suhu $40 \pm$ $5^{0} \mathrm{C}$ selama 24 jam, lalu didinginkan hingga suhu kamar.

Dipipet 25,0 $\mathrm{ml}$ masing - masing larutan contoh dan ditambahkan larutan asetilaseton amonium asetat sebanyak 25,0 $\mathrm{ml}$ ke dalam labu ukur $100 \mathrm{ml}$ kemudian diencerkan hingga tanda batas.

Kemudian dipanaskan dalam penangas air pada suhu $60 \pm 5^{\circ} \mathrm{C}$, selama 10 menit, diangkat dan didinginkan hingga suhu kamar. Kemudian dilakukan pengukuran dengan spektrofotometer pada panjang gelombang $412 \mathrm{~nm}$. Dengan absorbansi yang didapat dari pembacaan spektrofotometer, selanjutnya dilakukan perhitungan konsentrasi formaldehida dengan menggunakan regresi terhadap larutan deret standar. (Tabel 1.)

\section{HASIL DAN PEMBAHASAN}

\section{A. Sifat Fisika - Kimia Perekat Tanin Resorsinol Formaldehida}

Perekat Tanin Resorsinol Formaldehida (TRF) yang dibuat dengan nisbah mol tanin : resorsinol : fortmaldehida $=1: 0,5: 2$, berbentuk cairan, berwarna cokelat tua, berbau khas fenol. Perekat ini termasuk perekat eksterior yang diharapkan dapat menggantikan perekat golongan fenolik dengan proses kempa dingin (cold set) seperti resorsinol formaldehida (RF) dan fenol resorsinol formaldehida (PRF) yang sampai saat ini masih impor. Karakteristik TRF dapat dilihat pada Tabel 2.

\section{B. Bobot jenis}

Bobot jenis rata - rata yang dihasilkan dari papan lamina yang terbuat dari kombinasi jenis kayu dengan menggunakan perekat TRF sebagai perekatnya adalah berkisar antara 064 0,85 (Tabel 3).

\section{Kadar Air}

Kadar air rata - rata papan lamina yang terbuat dari kombinasi jenis kayu batang kelapa dengan menggunakan perekat TRF sebagai perekatnya ini berkisar antara 10,64 - 11,52 \% (Tabel 4), dan seluruhnya memenuhi persyaratan Standar karena nilainya kurang dari $15 \%$ (JAS, 2003).

\section{Emisi Formaldehida Kayu Lamina}

Kayu lamina dari kombinasi jenis kayu hutan tanaman dan kayu kelapa yang dibuat dengan perekat tanin resorsinol formaldehida (TRF) dalam penelitian ini menghasilkan emisi formaldehida rata-rata berkisar antara 0,0695 - 0,1173 mg/L (Tabel 5). Sedangkan Emisi formaldehida yang paling rendah diperoleh dari kayu lamina dengan kombinasi jenis kayu kelapa - mangium adalah 0,0695 mg/L, sementara yang dibuat dari kombinasi kelapa - gmelina $0,1173 \mathrm{mg} / \mathrm{L}$ mempunyai nilai emisi formaldehida yang paling tinggi (Tabel 5).

Dari Tabel 6, dapat terlihat bahwa emisi formaldehida yang dihasilkan dari papan lantai lamina dengan kombinasi jenis kayu dan batang kelapa cenderung meningkat pada kayu penyusunnya yang berbobot jenis semakin rendah. 
Kenaikan emisi formaldehida dengan turunnya bobot jenis kayu pelapis kayu batang kelapa lebih jelas dengan grafik histogram (Gambar 3).

Kayu dengan bobot jenis tinggi menunjukkan bahwa dinding sel kayu tebal dan sebaliknya bobot jenis rendah mengisyaratkan dinding sel kayu tipis. Pada kayu yang berbobot jenis tinggi tingkat kerapatan por- pori kayu lebih rapat daripada kayu yang berbobot jenis rendah. Hasil penelitian ini tidak sama dengan hasil penelitian Juhendi (1998), yang meneliti tentang emisi formaldehida pada panel kayu Meranti Merah (Shorea. spp, $\mathrm{BJ}=0,53$ ) dan Kapur (Drybalanops spp, $\mathrm{BJ}=0,59)$. Dalam penelitian tersebut dikemukakan bahwa emisi formaldehida dari panel kayu Meranti Merah rata-rata lebih rendah daripada kayu Kapur.

Dugaan bahwa peranan bobot jenis kayu cukup berpengaruh terhadap emisi formaldehida dari produk kayu yang direkat dengan perekat yang mengandung formaldehida ditunjukan pula oleh Memed (1987) yang meneliti emisi formaldehida papan partikel dari beberapa jenis kayu, antara lain Meranti Merah dan Meranti Kuning (Shorea gibbosa, S. brandis, BJ rata - rata 0,51) dengan menggunakan perekat Urea Formaldehida atau Phenol Formaldehida. Hasil penelitian ini mengemukakan bahwa emisi formaldehida papan partikel dari kayu meranti merah lebih rendah daripada papan partikel kayu meranti kuning.

Berdasarkan hal tersebut dapat dikemukakan bahwa panel kayu yang dibuat dari jenis kayu yang memiliki bobot jenis rendah, tidak selalu memiliki emisi formaldehida yang lebih tinggi daripada panel kayu yang dibuat dari kayu yang berbobot jenis tinggi. Hal tersebut di atas berlaku dalam penelitian yang dilakukan dengan kombinasi kayu dan kelapa menggunakan perekat tanin resorsinol formaldehida. Walaupun hasil uji cenderung menunjukkan bahwa nilai emisi formaldehida kayu lamina semakin meningkat dengan semakin rendahnya jenis kayu penyusun (Tabel 6), menurut sidik ragam bobot jenis kayu penyusun kayu lamina ternyata tidak berpengaruh terhadap kadar emisi formaldehida yang dihasilkan (Tabel 8). Hal ini diduga berkaitan dengan rendahnya kadar formaldehida bebas yang terkandung dalam perekat tanin yang digunakan dan sifat dari perekat tanin tersebut yang tahan terhadap air.

Walaupun produk perekatannya diperlakukan dalam kelembaban yang tinggi, tidak terjadi hidrolisis terhadap perekat tanin sehingga tidak terjadi emisi formaldehida dari produk perekatan tersebut.

$\begin{array}{ccc}\text { Secara } & \text { keseluruhan emisi } \\ \text { formaldehida kayu lamina yang }\end{array}$
menggunakan jenis kayu penyusun berbeda dan berperekat tanin resorsinol formaldehida ini memenuhi persyaratan standar Jepang (JAS, 2003) untuk kategori $\mathrm{F}^{* * * *}$ (sangat aman), karena nilai rata ratanya $<0,3 \mathrm{mg} / \mathrm{L}$ dan maksimumnya < $0,4 \mathrm{mg} / \mathrm{L}$ (Tabel 7).

Tabel 1. Larutan Deret Standar.

\begin{tabular}{|c|c|c|}
\hline Labu Ukur no. & $\begin{array}{l}\text { Larutan Standar } \\
\qquad(\mathrm{ml})\end{array}$ & $\begin{array}{l}\mathrm{H}_{2} \mathrm{O} \\
(\mathrm{ml})\end{array}$ \\
\hline 1 & 0.00 & 100 \\
\hline 2 & 5.00 & 95 \\
\hline 3 & 10.00 & 90 \\
\hline 4 & 20.00 & 80 \\
\hline 5 & 50.00 & 50 \\
\hline 6 & 100.00 & 0 \\
\hline
\end{tabular}


Tabel 2. Karakteristik Perekat Tanin Resorsinol Formaldehida (TRF)

\begin{tabular}{|c|c|c|}
\hline \multirow[b]{2}{*}{ Pengujian } & \multicolumn{2}{|c|}{ Jenis perekat } \\
\hline & TRF & Standar (PRF)* \\
\hline Uji visual & $(+)$ & $(+)$ \\
\hline Bahan Asing & $(-)$ & $(-)$ \\
\hline Waktu tergelatin (menit) & 100,5 & 85 \\
\hline Kadar resin padat $(\%)$ & 32,72 & 57,03 \\
\hline Viskositas $\left(25 \pm 1^{\circ} \mathrm{C}\right)$, (poise) & 0,88 & 3,4 \\
\hline Keasaman $(\mathrm{pH})$ & 10,62 & 8,0 \\
\hline Bobot jenis & 1,14 & 1,15 \\
\hline Formaldehida bebas $(\%) *$ & 0,30 & 0,04 \\
\hline
\end{tabular}

Keterangan: (+) Cairan berwarna coklat sampai hitam, berbau khas;

(-) Tidak ada

- Syarat Formaldehida bebas dalam perekat max $3 \%$ (SNI)

Tabel 3. Bobot Jenis Kayu Llamina dari Kombinasi Jenis Kayu

\begin{tabular}{llllll}
\hline \multirow{2}{*}{ Kombinasi } & \multicolumn{5}{c}{ Bobot Jenis } \\
\cline { 2 - 6 } & Ulangan 1 & Ulangan 2 & Ulangan 3 & Total & Rata - rata \\
\hline Kelapa - kelapa & 0,88 & 0,84 & 0,85 & 2,57 & 0,85 \\
Kelapa - jati & 0,76 & 0,75 & 0,77 & 2,28 & 0,76 \\
Kelapa - mangium & 0,70 & 0,75 & 0,73 & 2,18 & 0,73 \\
Kelapa - tusam & 0,71 & 0,68 & 0,72 & 2,11 & 0,70 \\
Kelapa - gmelina & 0,65 & 0,62 & 0,66 & 1,93 & 0,64 \\
\hline
\end{tabular}

Tabel 4. Kadar Air Kayu lamina dari Kombinasi Jenis Kayu Batang Kelapa

\begin{tabular}{llllll}
\hline \multirow{2}{*}{ Kombinasi } & \multicolumn{5}{c}{ Kadar Air (\%) } \\
\cline { 2 - 6 } & Ulangan 1 & Ulangan 2 & Ulangan 3 & Total & Rata - rata \\
\hline Kelapa - kelapa & 10,56 & 10,94 & 11,63 & 33,13 & 11,04 \\
Kelapa - jati & 11,03 & 11,62 & 11,92 & 34,57 & 11,52 \\
Kelapa - mangium & 10,56 & 11,35 & 11,68 & 33,59 & 11,20 \\
Kelapa - tusam & 10,08 & 10,63 & 11,20 & 31,91 & 10,64 \\
Kelapa - gmelina & 10,12 & 10,55 & 11,28 & 31,95 & 10,65 \\
\hline
\end{tabular}


Tabel 5. Emisi Formaldehida Kayu Lamina Kombinasi Jenis Kayu dengan Batang Kelapa Berperekat TRF.

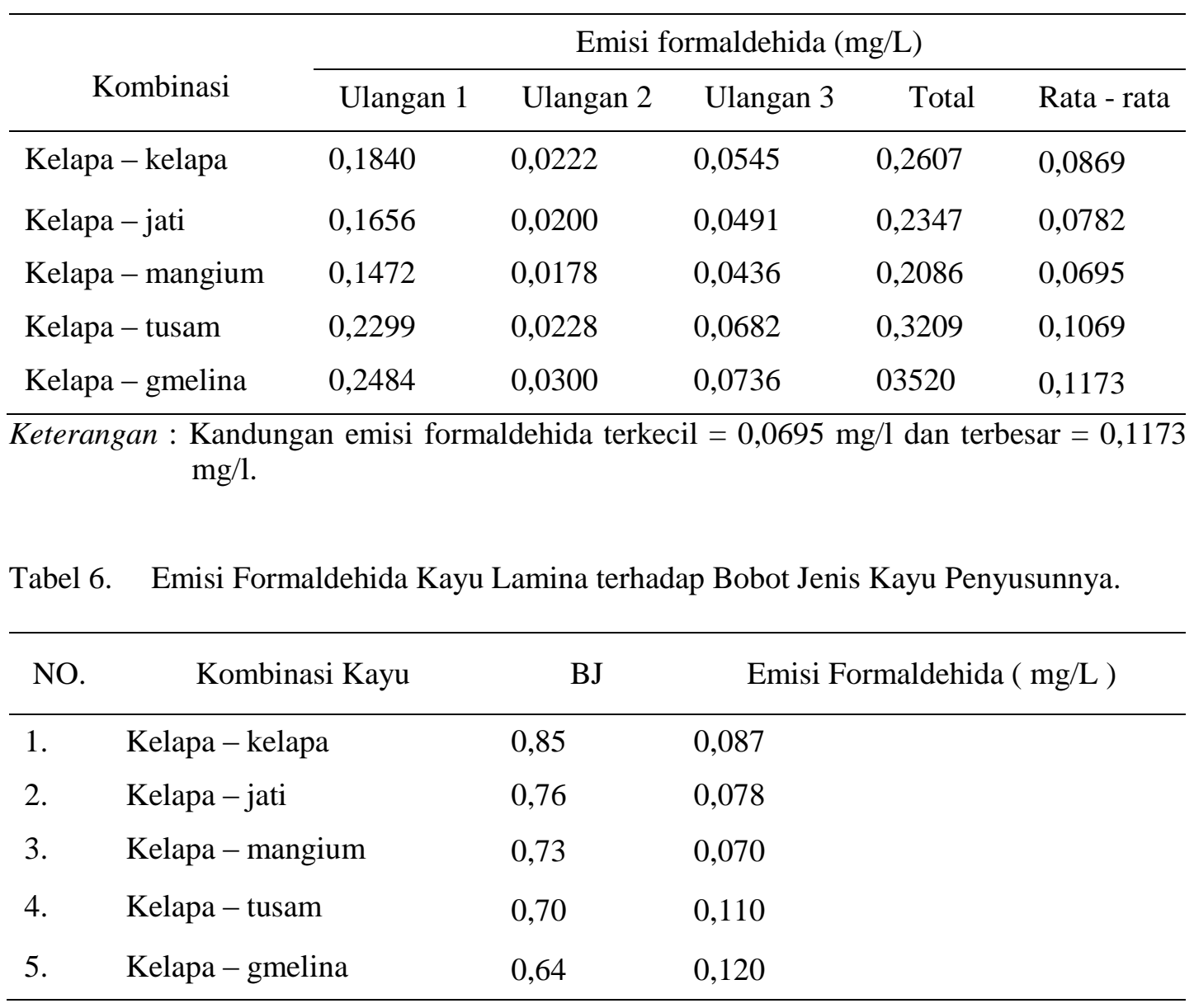

Histogram Emisi Formaldehida

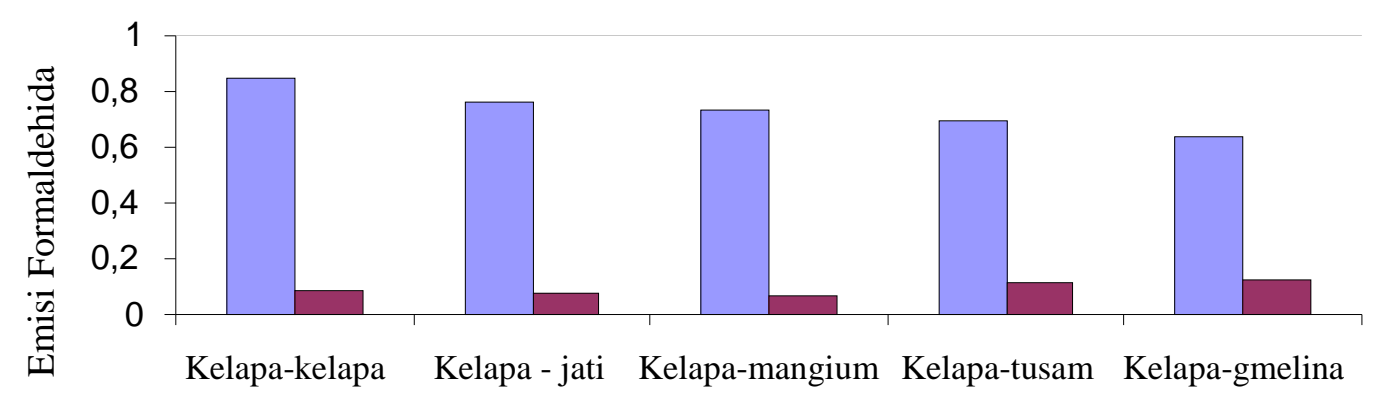

BJ kayu penyusun

$\square$ Bobot Jenis $\quad \square$ Emisi Formaldehida

Gambar 3. Histogram emisi formaldehida kayu lamina dengan bobot jenis 
Tabel 7. Persyaratan Emisi Formaldehida (JAS,2003)

\begin{tabular}{lccc}
\hline Kategori Kelas & $\begin{array}{c}\text { Nilai rata }- \text { rata } \\
(\mathrm{mg} / \mathrm{L})\end{array}$ & $\begin{array}{c}\text { Maximum } \\
(\mathrm{mg} / \mathrm{L})\end{array}$ & Keterangan \\
\hline $\mathrm{F} * * * *$ & 0,3 & 0,4 & Sangat aman \\
$\mathrm{F} * * *$ & 0,5 & 0,7 & Aman \\
$\mathrm{F} * *$ & 1,5 & 2,1 & Kurang aman \\
$\mathrm{F} * \mathrm{~S}$ & 3,0 & 4,2 & Tidak aman \\
\hline Sumber: JIS A 5908:2003 & & &
\end{tabular}

Sumber: JIS A 5908:2003

Tabel 8. Sidik ragam emisi formaldehida kayu lamina kombinasi kayu dan kelapa

\begin{tabular}{|c|c|c|c|c|c|c|}
\hline \multirow{2}{*}{ Sumber keragaman } & \multirow[b]{2}{*}{$\mathrm{db}$} & \multirow[b]{2}{*}{ JK } & \multirow[b]{2}{*}{ RJK } & \multirow[b]{2}{*}{$\mathrm{F}_{\text {-hitung }}$} & \multicolumn{2}{|c|}{$\mathrm{F}_{\text {- tabel }}$} \\
\hline & & & & & 0,05 & 0,01 \\
\hline Kombinasi kayu & 4 & 0,00634 & 0,00159 & $0,28^{\mathrm{tn}}$ & 3,06 & 4,89 \\
\hline Galat & 15 & 0,08633 & 0,00576 & & & \\
\hline Jumlah & 19 & 0,09268 & & & & \\
\hline
\end{tabular}

Keterangan : ${ }^{\text {th }}$ Tidak berpengaruh nyata.

\section{KESIMPULAN DAN SARAN}

\section{A. Kesimpulan}

Perekat tanin resorsinol formaldehida (TRF) dapat diaplikasikan sebagai perekat untuk papan lantai lamina yang terbuat dari kombinasi jenis kayu dengan batang kelapa karena ternyata tidak dipengaruhi oleh jenis kayu penyusunnya maupun bobot jenis kayu itu sendiri dan emisi formaldehida yang dihasilkan tidak berpengaruh nyata.

Dari kelima jenis kayu yang digunakan, yang memiliki emisi formaldehida paling rendah adalah kombinasi kayu kelapa - mangium $(0,0695-01472 \mathrm{mg} / \mathrm{L})$ dan paling tinggi adalah kombinasi kayu kelapa - gmelina $(0,1173$ - 0,2484 mg/L.

Secara umum emisi formaldehida dari papan lantai lamina yang diperoleh masih termasuk dalam kategori $\mathrm{F}^{* * * *}$ (sangat aman) dan kadar air yang dihasilkan masih memenuhi persyaratan (kurang dari 15\%), hasil penelitian tertinggi $11,92 \%$ (JAS, 2003)

\section{B. Saran}

Perlu dilakukan penelitian lebih lanjut mengenai penggunaan perekat TRF terhadap umur warna kayu lamina yang dipakai dalam suatu produk sehingga dapat mempengaruhi kestabilan warna dengan menggunakan uji kestabilan.

\section{DAFTAR PUSTAKA}

Anonim, 1974. Wood Hand Book : Wood as an Engineering Material, Forest Product Laboratory, Forest Service Departement of Agricultural, Washington.

Barly, 2001. Pengolahan dan Pemanfaatan Batang Kelapa. Petunjuk Teknis, Pusat Litbang Teknologi Hasik Hutan, Bogor. 
Blanchet P. R. A., Bearegard, Erb and M Leverbvre, 2003. Comparatice study Of Four Adhesive Used as Binder in Engineered Wood Parquet Flooring, Forest Product Juornal, Vol. 53 : 89 - 93.

Christensen R. P., Robincheck and J. Stone, 1981. Formaldehyde Emision from Particleboard. Holz als Roh-und Werkstoff, 39 : 231 - 234.

JAS (Japanese Agricultur Standard), 2003. Japanese Agricultur Standard for Glued Laminated Timber, Notificatoin No. 234 February 27, 2003.

Juhendi, A. J., 1998. Pengaruh Jenis Kayu dan Jumlah Lapisan terhadap keteguhan Rekat dan Emisi Formaldehida Kayu Lapis (Skripsi), Bandung : Jurusan Teknologi Hasil Hutan, Fakultas Kehutanan, Universitas Winaya Mukti.

Martawidjaya, A. 1990. Sifat dasar beberapa jenis kayu yang berasal dari hutan

Memed, R.,1990. Pengaruh melamin dalam perekat urea formaldehida terhadap beberapa sifat kayu lapis meranti.

Petterson, R., 1976. Assesment of Formaldehida as Poteential Air Pollution Problem in an Annoted Bibliographi by FH. Product Laboratory, Madison WIS.47.

Pizzi, A., 1994. Advanced Wood Adhesive Technology, New York. Marcel Dekker.

Roffael, E., 1993. Formaldehida Release from Particleboard and Other Wood Based Panels, Kuala Lumpur, Forest Research Institute Malaysia.

SNI (Satndar Nasional Indonesia), 1998. Kumpulan SNI Perekat. Badan Standarisasi Nasional (BSN), Jakarta.

Sutigno, P. 1988. Perekat dan Perekatan. Badan Litbang Departemen Kehutanan, Bogor.

Tsoumist, G. 1991. Science and Technology of Wood : Structure properties Utilization, Van Notrand Reinhold, New York. Yap, 1984. Konstruksi Kayu, Bina Cipta, Bandung. 